\title{
Exploring EFL Students' Reading Engagement in KWL Strategy
}

\author{
Anisyafa Firda Dwi Damaranti \\ Anisyafa.firda08@gmail.com \\ Hilmansyah Saefullah \\ Hilmansyah.saefullah@fkip.unsika.ac.id \\ Iwan Ridwan \\ Iwan.ridwan@fkip.unsika.ac.id \\ Universitas Singaperbangsa Karawang
}

\begin{abstract}
This research attempted to explore how the KWL strategy facilitates EFL students' reading engagement. The participants of this research were three students of an Islamic Senior High School. Using a case study design, the researcher describes EFL students' reading engagement by observing and engaging them in in-depth interviews. For gaining the data, the researchers used semi-structured interviews and the students' artefacts of the KWL tables. The interview session was conducted through WhatsApp audio-recording as a preferred interview media by the participants. The result of the research found that the KWL strategy gives positive engagement and self-assessment to EFL students with several stages. Other researchers are suggested to conduct further research on similar topics related to reading engagement in EFL students. Several research possibilities will expand this research. First, future researchers can complete this study by looking at the students' needs in the classroom. The results of this study revealed that students have difficulty with vocabulary.
\end{abstract}

Keywords: KWL Strategy; Reading Skill; Students’ Engagement

\section{INTRODUCTION}

Reading is considered as the most fundamental to learning English, especially for English as a foreign language (EFL) learners. However, EFL students still face a substantial problem in mastering the reading skill, especially understanding the meaning in the text (Noursi, 2013; Rahmawati 2018). This statement is supported by the students of the eleventh grade of an Islamic Senior High School. They argued that their obstacle was derived from students' interest and conceptual understanding they encountered while reading the text.

Students' level of interest and attention during the learning process is defined as engagement and it allows the transition of knowledge to the learning context (Rahmanpanah \& Mohseni, 2017; Savin-Baden, 2016). One of the comprehension strategies to understand that can be used by EFL students is the KWL strategy. 
KWL strategy is a teaching and learning strategy using three-column tables, those are What I Know, What I Want to Know, and What I Learned. KWL strategy was developed by Ogle in 1986. By encouraging the students' engagement in reading text, KWL strategy is a target to inspire highly engaged learning in this research.

In recent years, researchers have reported that KWL strategies can facilitate EFL students to understand English texts. Riswanto, et al, (2014) reported that KWL strategy helped students in understanding the reading material easily. Rahmawati (2018) found out that KWL strategy is able to improve students' reading comprehension. Pagani (2019) focused on KWL strategy as a possible model to connect self-assessment and feedback, the result of her study concluded that KWL model is a valuable method. Based on the previous research studies, KWL strategy can be an alternative strategy for EFL teachers for teaching comprehension skill in reading English texts. However, the nature of EFL students' reading engagement in the KWL strategy has not been much investigated. Therefore, to fill this gap, this research aims to explore how KWL strategy facilitate students' reading engagement.

\section{LITERATURE REVIEW}

\section{Previous Study}

The previous study was done by Rahmawati (2018) with the title "Analysis of Students' English Reading Comprehension through KWL (Know-Want-Learn) Learning Strategies". Researcher intends to know the reading comprehension of students through KWL learning strategies. study was conducted by carrying out a reading test using a test, after that applying the KWL learning strategy. It was found that the KWL strategy is able to improve students reading comprehension.

Lianisya (2014) used a case study in her research. Her study was conducted to investigate the use of self-assessment towards students' reading behavior using KWL (Know-Want-Learnt) framework, which included twelfth grader students of a private high school in Bandung. The use of the KWL framework in the classroom can motivate students to be actively involved in reading activities. Furthermore, in collecting data using interviews, she got a positive response from students since the use of the KWL framework able to help students maintain their reading behavior. This statement is supported by Dieu (2015) that "As a result, the research has proved the effectiveness of the treatment. It is also suggested how to control a reading class, to create an interesting and exciting atmosphere to improve students' reading comprehension skill". It proves that the use of KWL strategy can improve students reading comprehension and has positive respons on students' behaviour.

\section{Students' Engagement}

Students' level of interest and attention during the learning process is defined as engagement. It allows the transition of knowledge to the learning context 
(Rahmanpanah \& Mohseni, 2017; Savin-Baden, 2016); it also drives academic success (Liu et al., 2018). Measured from several dimensions, student engagement in the reading text contains students' cognitive, motivational, and behavioural characteristics. In line with this, Roe (2016) stated that reading engagement includes motivation, cognitive engagement, and text receptivity.

The first dimension is behavioural engagement. In this dimension, student involvement can be seen in the classroom. Participation in the classroom includes student behaviour and students' attention. This is necessary to achieve a positive result. Then, emotional engagement is student involvement, such as enthusiasm for following lessons or in the classroom. When students are emotionally involved, they will voluntarily participate and enjoy classroom activities. Last, cognitive engagement is part of a student's involvement. It is defined as a student's investment in learning. Students have to participate and be active in the learning process. This involvement aims to make students enthusiastic in the classroom. Thus, a student may have positive engagement, non-engagement, or negative engagement along the behavioural, emotional, or cognitive dimensions.

Reading engagement includes reading for pleasure and commitment and persistence by the reader in reading a text to get or obtain specific purposes. Based on Patel and Jain (2008) state as follows "Reading is an important activity in life with which one can update his/her knowledge. Reading skill is an important tool for academic success. Reading is the most important activity in any language class. Reading is not only a source of information and pleasurable activity but also a means of consolidating and extending one's knowledge of the language. Reading is very necessary to widen the mind, again and understanding of the foreign culture" ( $p$. 113-114).

\section{KWL Strategy}

The definition of KWL strategy is one of the teaching and learning strategies used for information text. KWL strategy is a teaching and learning strategy using threecolumn tables developed by Ogle in 1986: What I Know, What I Want to Know, and What I Learned. According to Fisher and Frey (2010), the KWL strategy is often used as a reading strategy. This strategy is a way to facilitate the students' metacognitive thinking process, which is made simply in the form of a chart. The first column is "K," or what I Know, which stands for what students already know about the topic. The second column is "W," or what I Want to know, which stands for what the student will learn. The third is "L," or what I learned, which means what they have learned about the topic.

Some previous studies applied this strategy. Dieu (2016) found out in his study that the KWL strategy motivated students' academic success because they could more connect their knowledge to subjects. Also, Widiartini and Sudirtha (2019) had applied the KWL (Know-What-Learn) strategy in their study. They found that the 
KWL strategy allows students to find conceptual relationships to construct their understanding.

\section{METHOD}

\section{Design and Samples}

This study can be classified as a case study since the focus of this design is on a phenomenon within a real-life context. A case study design is well suited for answering the research questions of this study. In addition, using a case study design, the researchers can describe clearly by observing them within a virtual classroom context and engaging them in in-depth interviews. The participants of this research are three students of grade eleventh from an Islamic Senior High School in the 2020/2021 academic year. The researchers asked 3 students voluntarily to share their experiences about a particular case using the KWL strategy.

\section{Instrument and Procedure}

In obtaining data of students' perceptions, the researchers collected the data from observation, and semi-structured interviews. Furthermore, to obtain more detailed data in revealing the problem, observation was conducted through a virtual classroom using semi-structured interviews and students' artefacts. The interview session was conducted through WhatsApp audio-recording in Indonesian, and the recording was then transcribed into English.

\section{Data Analysis}

In order to produce findings that could sustain the research question, this research was analysed by using a generic inductive approach as data analysis. According to Thomas (2006), he argued that "The general inductive approach provides a convenient and efficient way of analysing qualitative data for these purposes." (p. 246). To categorize the data to be distributed into three different types of engagement with several procedures adapted by Thomas, D. R. (2006). First, prepare raw data files in the form of interviews. Second, a close reading of the text; after the text is ready, the text is read in detail by the researchers to be familiar with the content and understand the themes and events covered in the text. Third, categorize them by identifying and defining themes, and fourth, coding relevant to the theme, and lastly, perfecting the theme by choosing appropriate quotes.

\section{FINDINGS \& DISCUSSION}

\subsection{Motivational Engagement}

In this component, students have different reasons for reading motivation. According to Guthrie \& Wigfield (2000), they argued that students' motivation to 
read texts is very diverse. In this study, the researchers found that students have positive responses towards motivational engagement, as shown in,

"Yes, it makes me very interested. I don't know why it's so fun. First, we have to fill in what we know (K column) from the topic we are going to read. This is a really fun stage. Because I was not asked to think, but I was also invited to dig up the information I've received. It's related to the topic I have read, so it's like being invited to explore again. Second, how should we fill in what we want to know (W column), huh? At this stage, it can also be used as material for self-reflection. From how much information I already know until this moment. Also, how many books/information have I read or received? Thirdly, where should we fill in what we already know from the text right? This is the point because, for me, who usually reads text by reading normally, I don't have a single thing of information that I got. Because I just read the title normally. Then when I read the text using the KWL strategy, it's not just the text that I have read, but in the end, I got one insight or new information that I just found out."

(Vignette 1, Student A)

"Yes, I'm interested. Because with this strategy, it is easy for me to understand. The reason is easy for me because in the first and the second KWL column..like...I should write it first, so it is easier to me to find new information."

(Vignette 2, Student B)

In this study, it was found that the KWL strategy is interesting, easy to understand, and motivating them in reading the texts. Also, the KWL strategy helping them to understand the text better since they filled the KWL column easily. Most of the students claimed that the KWL strategy in the reading text made them gain valuable information, which would help give them a better grasp of the understanding. These students' vignettes showed that student A provides evidence of her motivation to read. In the first column, she explained that she was very interested because she explored the information. In the second column, student A said that it is like a selfreflection for her because she knew how far she understands the topic. In the last column, student A said that this column was very important for her because she got the information after using this strategy. She argued that she never gets the point when reading normally without the KWL strategy. She shared that she was interested because she had never used any strategy before, and by using this strategy, student A got a good end-result by getting new information.

In contrast to student A, student B argued that she was interested in this strategy because it was easier to understand. After all, she perceived that she was guided to write it first in the first and second KWL columns. She believed it made her easier to find new information from the text that she had read. Meanwhile, student $\mathrm{C}$ assumed that this strategy made her quite interested in filling out the KWL column. As shown in,

"I'm quite interested, sis. Because what I said earlier, the thing that intrigued me was just the contents of the columns."

(Vignette 3, Student C) 
Student C's vignette indicated that her interest in the KWL strategy made her interested because she felt curious to fill the KWL column. Therefore, by using this KWL strategy, students were encouraged to fill in the KWL column that has been provided, and students were involved in filling out the columns indirectly. This component reflected that the use of the KWL strategy has a positive impact on EFL students.

\subsection{Cognitive Engagement}

Skilling \& Styliandes (2015) state that "Cognitive engagement includes thinking deeply and broadly about concepts when using strategies such as organization, practice, and elaboration as well as organizing and managing the learning process." (p. 1280). In this component it was found out that the level of the students' cognitive involvement was various. This was influenced by their goals, the strategies used by students, and also motivational factors. In this study, the students were challenged to be proactive by seeking additional conversations (questions) with the teacher to explore the topic of reading. In observations, it was found out that the students were quite active in asking questions in class. However, there are still some passive students in the classroom. The students' cognitive engagement can be seen from their performance on doing the task of filling up the KWL table.

The two artefacts of students' KWL columns showed that the cognitive aspect of student engagement was effective in helping them to understand the text pretty well. This aspect can be seen that the students A and B meet the assignment requirements very well. This is evidenced by how well they submitted their works with the assignment requirements in every learning process. Student $\mathrm{C}$ has done the task smoothly by identifying and meeting the requirements. It was found that the use of this strategy helped students in meeting the requirements even though there were still difficulties faced by her. She argued that when she filled out one of the columns, she was quite clueless. At this stage, the teacher's role is needed in guiding students' problems.

\subsection{Behavioural Engagement}

Behavioral engagement includes students' participation in lessons, such as attendance and focus levels, as well as their engagement in social aspects of learning, and whether they are involved in activities or not, as shown in,

"On the one hand, it really helps me focus on understanding the text because it's already organized, so it's like I already know where I want to focus on."

(Vignette 7, Student A)

"Yes, I felt like I'm more focused on the text. We're told to fill in the column like that, right? When we fill the column, it means that our focus at that time is on the text we're reading. So I think yes."

(Vignette 8, Student B)

"Yes, because in my opinion, by using this strategy, readers will focus more on understanding the text because it is easy to use too." 
(Vignette 9, Student C) These student's vignettes showed that the KWL strategy helped them understand the text they read. Furthermore, the KWL table helps student A organize what to read to know what things they want to focus on immediately. Student B argued that she was more focused when reading a text. She believed using the KWL strategy helping her focus on the text. Meanwhile, student $\mathrm{C}$ mentioned that the KWL strategy helped her more focus because it is easier for her to focus when reading the text.

Moreover, students viewed the learning process through the KWL strategy as positive learning, and it was beneficial for them because they were directly involved during the learning process. The learning process using the KWL strategy has encouraged students to learn and build their understanding and interest in reading English texts. The findings of this component reflected that the use of the KWL strategy facilitates EFL students' reading engagement in the classroom. The KWL strategy found positive responses from EFL students such as being motivated, interested, and able to build an understanding of the text. Several stages in using this strategy are introducing and explaining the KWL strategy, sharing and asking them to fill the KWL column, choose the topic and guiding students in brainstorming activities to generate the ideas to encourage students to think.

In short, using the KWL strategy in the classroom can facilitate them to be actively involved in the learning process, especially in reading activities with several stages. Furthermore, the KWL strategy found positive responses from EFL students in these components, such as being motivated, interested, and able to build an understanding of the text. This finding reflects the result of other previous studies that the process of KWL strategy was effective for learning reading (Rahmawati, E., 2018 and Riswanto, et al., 2014). Some things to note are the teacher's role in the classroom also plays an essential role in guiding them to maximize students' engagement.

\section{CONCLUSION}

Based on the research findings, this study discusses how the KWL strategy facilitates students' engagement in reading comprehension. The students revealed positive responses towards the use of the KWL strategy in students' engagement. It can be concluded that using the KWL strategy in the classroom can facilitate them to be actively involved in the reading learning acivities with several stages. Furthermore, the KWL strategy found positive responses from EFL students, such as being motivated, interested, and able to build an understanding of the text. Nevertheless, some unfavourable responses from students who stated that they were less interested in using the KWL strategy and had difficulty filling the KWL columns. This is due to the vocabulary they did not know before. 


\section{REFERENCES}

Dieu T T. (2016). Trying KWL strategy on teaching reading comprehension to passive student in Vietnam. International Journal of language and linguistics. 3(6): 481-492.

Guthrie, J. T., \& Wigfield, A. (2000). Engagement and motivation in reading. In M. L. Kamil, P. B. Mosenthal, P. D. Pearson, \& R. Barr (Eds.), Handbook of reading research (p. 403-422). London: Lawrence Erlbaum Associates.

Noursi, O.A. 2013. Attitude towards Learning English: The case of the UAE Technological High School. Institute of Applied Technology, Abu Dhabi, $U A E$.

Ogle, D.M. 1986. KWL: A Teaching Model that Develops Active Reading of Expository Text. Reading Teacher. Retrieved from http://www.indiana.edu/ 1517/KWL.htm.

Pagani, V. (2019). KWL, a possible model to connect self-assessment and feedback: the students' view. Paper presented at the "Teaching, Learning \& Education" conference (Berlin, 15-17 May 2019). Taken from: https://iris.unive.it/retrieve/handle/10278/3717389/172250/ictle-52-162.pdf.

Patel, Dr. M.F \& Jain, Preveen M. (2008). English Language Teaching: Methods, Tools, \& Techniques. Jaipur: Surprise Publishers \& Distributors.

Rahmanpanah, H., \& Mohseni, A. (2017). Engagement and motivation in EFL classroom: Humanizing the course book or autonomy-supportive teaching climate? Journal of Language and Translation, 7(1), 69-88.

Rahmawati, E. Y. (2018). Analysis of Students' English Reading Comprehension through KWL (Know-Want-Learn) Learning Strategies. International Journal of Language Teaching and Education, 2(3), 238-247. https://doi.org/10.22437/ijolte.v2i3.5641.

Riantika, E., \& Setyaningsih, E. (2014). The Use of KWL (Know-Want to KnowLearned) Strategy to Improve Students Reading Comprehension. English Education, 2(2).

Riswanto, Risnawati, \& Lismayanti, D. (2014). The Effect of Using KWL (Know, Want, Learned) Strategy on EFL Students' Reading Comprehension Achievement. In International Journal of Humanities and Social Science. Vol. 4, No. 7 (1); may 2014.

Savin-Baden, M. (2016). The impact of transdisciplinary threshold concepts on student engagement in problem based learning: A conceptual synthesis. Interdisciplinary Journal of Problem-Based Learning, 10(2). https://doi.org/10.7771/1541-5015.1588.

Skilling, K. G., \& Stylianides, G. J. (2015). Promoting cognitive engagement in secondary mathematics classrooms. In Proceedings of the Ninth Conference of the European Society for Research in Mathematics Education (CERME9, 4-8 February 2015) (pp. 1280-1286). Ninth Conference of the European Society for Research in Mathematics Education (CERME9. https://hal.archives-ouvertes.fr/hal-01287357/document. 
Thomas, D. R. (2006). A General Inductive Approach for Analyzing Qualitative Evaluation Data. American Journal of Evaluation, 27(2), 237-246. https://doi.org/10.1177/1098214005283748

Widiartini, Ni K., and I. G. Sudirtha. "Effect of KWL Learning Method (Knowwant-learn) and Self-assessment on Student Learning Independence Vocational High School." International Journal of Social Sciences and Humanities, vol. 3, no. 2, 30 Aug. 2019, pp. 277-284, doi:10.29332/ijssh.v3n2.331. 